\title{
Analysis of p53-Dependency of Differentially Expressed Genes by Capsaicin in Human Colorectal Cancer Cell
}

\author{
Hyo-Eun Kim, Min-Jeong Jang, Seung-Hyun Lim, Hyo-Rim Kim, Soon-Young Kim, Gun-Joo Lee and \\ Jong-Sik Kim*
}

Department of Biological Sciences, Andong National University, Andong, 760-749, Korea

Received November 16, 2009 / Accepted November 30, 2009

\begin{abstract}
In the present study, we investigated anti-proliferative activities of capsaicin and gene expression changes in response to capsaicin treatment in human colorectal HCT116 cells. The results showed that capsaicin decreased cell viabilities in a dose dependent manner and induced global gene expression changes. We found that 103 genes were up-regulated more than twofold, whereas 153 genes were down-regulated more than twofold by $100 \mu \mathrm{M}$ capsaicin treatment. Among the up-regulated genes, we selected 4 genes (NAG-1,DDIT3, GADD45A and PCK2) and performed RT-PCR to confirm the microarray data. We found that $100 \mu \mathrm{M}$ of capsaicin increased tumor suppressor p53 gene expression. In addition, the results showed that NAG-1, DDIT3 and GADD45A expressions were not dependent on p53 presence, whereas $P C K 2$ expression. The results of this study may help to increase our understandings of the molecular mechanism of anti-proliferative activity mediated by capsaicin in human colorectal cancer cells.
\end{abstract}

Key words : Capsaicin, anti-proliferative activity, gene expression, p53, human colorectal cancer

\section{서 론}

고추에 함유되어 있는 대표적 생리활성 물질인 capsaicin (8-methyl- $N$-vanillyl-6-nonenamide)은 매운맛의 주성분이고 향신료, 식품 첨가물 또는 약제로 오래전부터 사용되었다 $[4$, 6]. Capsaicin에 대한 연구는 1950년대 capsaicin이 신경계, 특 히 통증 전달계에 미치는 영향이 알려지기 시작하면서 신경 생리학적인 효과에 대해 많은 연구가 이루어져 왔으며, 신경 세포의 capsaicin 수용기인 vanilloid 수용체(VR1)의 활성화로 감각신경과 작용하는 것으로 알려져 있다[26]. 또한, capsaicin 이 여러 가지 통증성 질환에 진통 효과가 있는 약제로 사용되 고 있어 임상적으로 중요한 위상을 차지하고 있으며, 진통 작 용 외에도 체지방을 줄여 비만의 예방과 치료에도 효과가 있 는 것으로 알려져 있다[12].

파이토케미칼에 의한 화학적 암 예방법의 관심이 높아지면 서 capsaicin에 대한 항암[25], 항염증[23] 및 항돌연변이[24] 활성 연구들이 이루어지고 있다. 최근 들어 capsaicin이 피부 [10], 대장[13], 방광[15], 간[17], 유방[5] 그리고 전립선[20]을 포함한 여러 종류의 암세포에서 apoptosis에 의한 세포사멸을 유도한다는 보고가 있다. 최근에는 전립선암 세포주에서 capsaicin에 의해 발현이 변화되는 유전자군을 선별하고, 또한 capsaicin에 의한 세포사멸과 관련된 후보 유전자군을 선별한 보고가 있었다[22].

\footnotetext{
*Corresponding author

Tel : +82-54-820-5798, Fax : +82-54-820-7705

E-mail : jsk@andong.ac.kr
}

암 억제유전자인 p53 유전자는 대표적인 전사조절인자로 서 많은 세포성장과정과 세포사멸에 관여하는 중요한 조절자 로 알려져 있다[3,18]. p53은 손상된 DNA 세포나 암세포의 성장을 억제하는 apoptosis를 유도하는 downstream 유전자 의 전사를 활성화 시킨다[8,28]. 또한 resveratrol [11], genistein [7], epigallocatechin-3-gallate [9], caffeic acid phenethyl ester [29] 등 많은 종류의 파이토케미칼이 p53 활성을 조절하 여 세포사멸에 관여한다고 알려져 있다. 따라서 $\mathrm{p} 53$ 유전자의 전사조절을 받는 downstream gene을 확인하는 것은 p53에 의한 세포사멸과 항암기전을 이해하는데 매우 중요할 것으로 생각된다.

따라서, 본 연구에서는 대장암 세포주 모델에서 파이토케미 칼 capsaicin의 항암 기전을 분자생물학적 기전 수준에서 이해 하기 위한 연구의 일환으로 oligo DNA microarray 실험을 수행하여 capsaicin에 의해 조절되는 유전자 군을 분석하였다. 또한, capsaicin에 의해 과대발현되는 유전자의 발현이 p53 의 존적인지 혹은 비의존적인지에 대해 연구하였다.

\section{재료 및 방법}

\section{세포주 및 파이토케미칼}

대장암 세포주 HCT116 세포주는 American Type Culture Collection (ATCC, USA)에서 구입하였고, p53 null인 HCT116 세포주는 Johns Hopkins 의과대학의 Bert Vogelstein 박사로부터 분양 받았다. 두 종류의 세포주 배양은 $10 \% \mathrm{FBS}$ (Fetal Bovine Serum, Gibco-BRL, USA), 1\% penicillin 및 
streptomycin (WelGene, Korea)이 포함된 Dulbecco's Modified Eagle Medium (DMEM, Gibco-BRL, USA)을 사용 하였다. 파이토케미칼인 capsaicin과 control로 사용된 DMSO (Dimethyl sulfoxide)는 Sigma사(USA)로부터 구입하여 사용 하였다.

\section{세포 생존율 연구}

대장암 세포주 HCT116에 capsaicin을 처리하여 세포 생존 율에 미치는 영향을 연구하기 위해 cell viability assay를 수행 하였다. 먼저 96 well plate에 well당 $3 \times 10^{3}$ 개의 세포를 접종하 고 24 시간 동안 배양한 후, capsaicin을 농도별 $(0,25,50,100$, $200 \mu \mathrm{M}$ )로 처리하였다. 24시간 처리 후 MTS 용액(Promega, USA)을 각 well 당 $20 \mu \mathrm{l}$ 씩 첨가하고 세포 배양기에서 4 시간 동안 반응시켰다. 이후 과정은 이전에 보고된 내용과 동일하 게 수행하였다[16].

\section{Oligo DNA microarray}

Oligo DNA microarray 실험은 미국 Microarrays사의 48.5 K Human Array-Illumina HEEBO oligo microarray를 사용하 였으며, 지노믹트리사(GenomicTree, Inc, Korea)에 위탁하여 수행하였다. 결과분석은 Genespring program 7.0 (Agilent, USA)을 이용하였으며, capsaicin의 처리에 의해 발현이 2배 이상 증가되는 유전자군과 감소되는 유전자군을 분석하였다.

\section{Western blot analysis}

Capsaicin을 농도별로 $(0,25,50,100 \mu \mathrm{M})$ 24시간 동안 처리 한 후, 세포를 수확하였다. 수확한 세포는 RIPA 용액을 첨가하 여 총 단백질을 분리하였다. 단백질 정량은 Bradford protein assay 용액(Bio-Rad, USA)을 사용하여 측정하였다. 총 $30 \mu \mathrm{g}$ 의 단백질을 취하여 $4 \sim 12 \%$ acrylamide gel (Invitrogen, USA)에 서 전기영동 한 후, nitrocellulose membrane (Invitrogen, USA)으로 electroblotting 하였다. 이후 Western blot 과정은 이전 보고된 방법과 동일하게 수행하였다[16]. 본 실험에서 사 용된 1차 항체로는 anti-NAG1, anti-ACTIN 항체가 사용되었 고, 2차 항체로는 horseradish peroxidase-conjugated goat anti-rabbit antibody, horseradish peroxidase-conjugated donkey anti-goat antibody를 사용하였다. NAG-1 항체를 제외한 모든 항체는 Santa Cruz사(USA)로부터 구입하였고, NAG-1 항체는 이전에 보고된 것을 사용하였다[1].

\section{RT-PCR 및 real-time PCR}

수확한 세포주로부터 추출한 total RNA $3 \mu \mathrm{g}$ 을 주형으로, M-MLV reverse transcriptase (Bioneer, Korea)를 이용하여 제 조사의 매뉴얼에 따라 $\mathrm{cDNA}$ 를 제조하였다. 합성된 cDNA 20 $\mu \mathrm{l}$ 에 증류수 $60 \mu \mathrm{l}$ 를 첨가하여 희석한 후, $\mathrm{PCR}$ (polymerase chain reaction)의 주형으로 사용하였다. 합성된 $\mathrm{cDNA}$ 를 주형
으로 하여 유전자 특이적인 oligo primer를 이용하여 PCR (polymerase chain reaction) 과정을 수행하였다. PCR mixture 는 2X PCR master mix (SeeGene, Korea)를 이용하였으며, $\mathrm{PCR}$ 반응은 $94^{\circ} \mathrm{C}$ 에서 5 분 denaturation시키고, $94^{\circ} \mathrm{C}$ 에서 30 초, $58^{\circ} \mathrm{C}$ 에서 30 초, $72^{\circ} \mathrm{C}$ 에서 30 초의 cycle을 25 번 반복한 후, 마지막으로 $72^{\circ} \mathrm{C}$ 에서 10 분간 반응시켰다. $\mathrm{PCR}$ product는 전 기영동하여 확인하였다. 정량적 real-time PCR은 $\mathrm{ABI}$ Prism 7500 cycler (Applied Biosystem, USA)를 이용하여 수행하였 다. Primer의 각각의 $\mathrm{Tm}$ 값은 Primer express 1.5 software program (Applied Biosystems, USA)을 이용하여 확인하였다. 주형으로 사용하는 $\mathrm{cDNA}$ 는 RT-PCR시 수행한 과정과 같은 방법으로 합성하고, 합성된 cDNA에 DNase-free water 180 $\mu \mathrm{l}$ 를 첨가하여 희석한 후 사용하였다. $\mathrm{PCR}$ mixture는 Power $\mathrm{SYBR}^{\circledR}$ Green PCR Master Mix (Applied Biosystems, USA)를 사용하였으며, 반응 조건은 첫 번째 step으로 $50^{\circ} \mathrm{C}$ 에서 2분, $95^{\circ} \mathrm{C}$ 에서 10 분간 반응시키고, 두 번째 step으로 $95^{\circ} \mathrm{C}$ 에서 15 초, $54^{\circ} \mathrm{C}$ 에서 30 초, $72^{\circ} \mathrm{C}$ 에서 33 초의 cycle을 40 번 반복하여 수행하였다. 결과는 ABI Prism 7500 SDS software program (Applied Biosystems, USA)을 이용하여 분석, 정량 하였으며 분석법으로는 comparative $\mathrm{Ct}$ (threshold cycle) method를 이 용하였다[19].

\section{결과 및 고찰}

\section{Capsaicin 처리에 의한 대장암 세포주 생존율 감소}

파이토케미칼 capsaicin이 대장암 세포주 HCT116의 생존 율에 미치는 영향을 확인하기 위하여 다양한 농도 $(0,25,50$, $100 \mu \mathrm{M})$ 의 capsaicin을 처리한 후, 세포 생존율 연구를 수행하 였다(Fig. 1). 그 결과, $25 \mu \mathrm{M}$ 와 $50 \mu \mathrm{M}$ 의 capsaicin 처리군에서 는 대조군과 비교해 보았을 때 큰 변화를 보이지 않은 반면, $100 \mu \mathrm{M}$ 와 $200 \mu \mathrm{M}$ 의 capsaicin을 처리한 경우 각각 $76.8 \%$ 와 $13.6 \%$ 의 생존율을 보여주었다. 이러한 세포생존율에 근거하

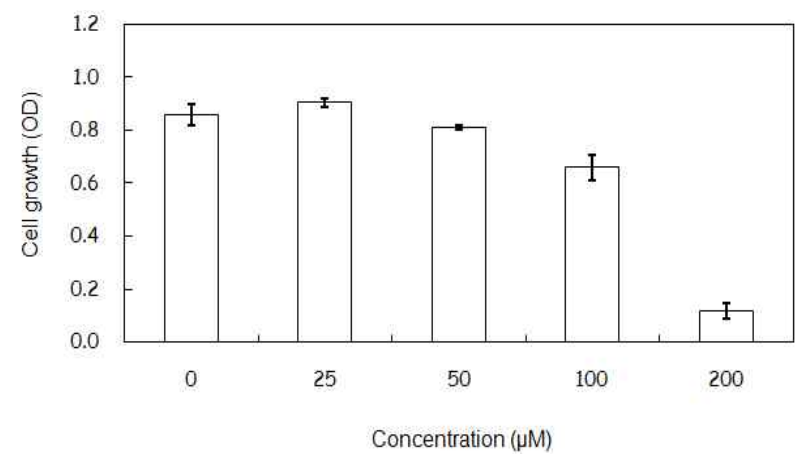

Fig. 1. Effect of capsaicin on HCT116 cell viability. HCT116 cells were treated with four different dose of capsaicin for 24 $\mathrm{hr}$. After treatment, cell viability was measured using cell proliferation assay kit. 
Table 1. Several up-regulated genes by $100 \mu \mathrm{M}$ capsaicin treatment

\begin{tabular}{cllc}
\hline Gene name & GenBank Acc. No. & \multicolumn{1}{c}{ Gene description } & Fold change \\
\hline SOD1 & NM_000454 & Superoxide dismutase 1, soluble & 12.08 \\
COBRA1 & NM_015456 & Cofactor of BRCA1 & 11.75 \\
GDF9 & NM_005260 & Growth differentiation factor 9 & 6.60 \\
S100P & NM_005980 & S100 calcium binding protein P & 5.71 \\
DENND1C & NM_024898 & DENN/MADD domain containing 1C & 4.91 \\
NAG1 & NM_004864 & NSAID activated gene-1 & 3.93 \\
PCK2 & NM_004563 & Phosphoenolpyruvate carboxykinase 2 & 3.11 \\
CDKN2B & NM_078487 & Cyclin-dependent kinase inhibitor 2B (p15, inhibits CDK4) & 3.05 \\
DDIT3 & NM_004083 & DNA-damage-inducible transcript 3 & 2.49 \\
GADD45A & NM_001924 & Growth arrest and DNA-damage-inducible, alpha & 2.39 \\
$T N F R S F 10 B$ & NM_003842 & Tumor necrosis factor receptor superfamily, member 10b & 2.29 \\
BAD & NM_004322 & BCL2-antagonist of cell death & 2.07 \\
\hline
\end{tabular}

여 대조군에 비해 $76.8 \%$ 의 생존율을 보여주는 $100 \mu \mathrm{M}$ 의 농도 를 선정하여 실험을 진행하였다.

Oligo DNA microarray를 이용한 유전체 전체 수준에서 의 유전자 발현 분석

Capsaicin에 의한 차별적으로 발현되는 유전자군을 선별하 기 위하여, HCT116 세포주에 $100 \mu \mathrm{M}$ 의 capsaicin을 24시간 동안 처리한 후, oligo DNA microarray 실험을 수행하였다. Capsaicin의 처리에 의해 발현되는 유전자 분석 결과, 2 배 이 상 발현이 증가된 유전자는 103 개, 2 배 이상 발현이 감소되는 유전자는 153개로 선별되었다(data not shown). 발현이 2배 이상 증가되는 유전자 중 일부를 Table 1에 나타내었다. 발현 이 2배 이상 증가되는 유전자 중 4 개의 유전자 $N A G-1, D D I T 3$, $G A D D 45 A, P C K 2)$ 를 선택하여 실험을 진행하였다. NAG-1 유 전자는 Baek 등에 의해 처음 보고된 항암유전자로서, 여러 가 지 Non-Steroidal Anti-Inflammatory Drugs (NSAIDs)와 파 이토케미칼에 의해 발현이 증가되어 여러 가지 생리활성 기능 을 가지는 것으로 보고되었다[1,2,30]. 그러나 capsaicin에 의한 $N A G-1$ 유전자의 발현 및 발현조절에 관한 보고는 아직까지 없다. DDIT3와 GADD45A 유전자는 nonivamide (pseudocapsaicin)에 의해 유전자 발현이 증가되고, DDIT3 유전자는 세포 사멸과 관련이 있다는 보고가 있었다[27]. 마지막으로 PCK2 유전자는 gluconeogenesis에 관련한 효소로서, 아직까지 capsaicin에 의한 발현과 조절에 대한 보고는 없다.

RT-PCR과 Western blot analysis를 통한 microarray 실험 결과의 검증

DNA microarray 실험 결과를 검증하기 위하여 2배 이상 증가되는 유전자 중 4 개(NAG-1, DDIT3, GADD45A, PCK2)를 선택하여 RT-PCR을 수행하였다. Fig. 2에서 보는 바와 같이 모든 유전자의 발현이 $100 \mu \mathrm{M}$ 의 capsaicin에 의해 up-regulation 되는 것을 확인할 수 있었고, 반면에 control로 사용한

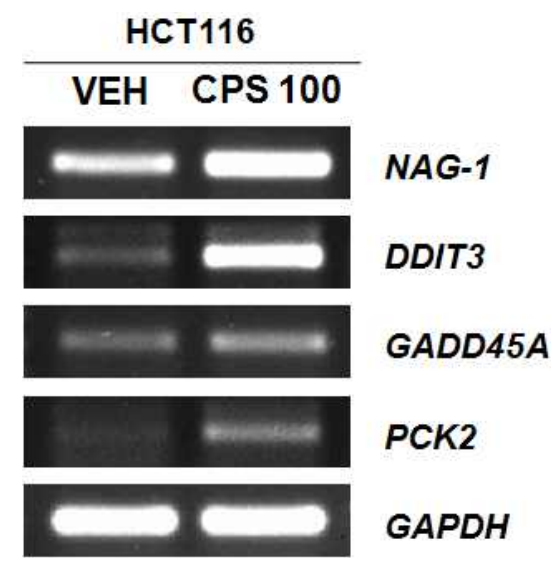

Fig. 2. Gene expression changes in capsaicin-treated HCT116 cells. HCT116 cells were treated with $100 \mu \mathrm{M}$ of capsaicin (CPS) or vehicle (VEH, DMSO). Total RNA was prepared for RT-PCR with gene specific primers.

$G A P D H$ 유전자의 발현 변화는 관찰되지 않았다.

Capsaicin에 의한 NAG-1의 발현을 단백질 수준에서 확인 하고자, 대장암 세포주 HCT116에 capsaicin을 농도별 $(0,25$, $50,100 \mu \mathrm{M})$ 로 24 시간 동안 처리하였다. 처리한 샘플에서 NAG-1 단백질의 발현을 확인하기 위하여 NAG-1 antibody를 이용하여 Western blot analysis를 수행한 결과, capsaicin의 처리 농도가 증가됨에 따라 NAG-1 단백질의 발현이 농도 의 존적으로 증가됨을 확인할 수 있었다(Fig. 3).

\section{Capsaicin에 의한 tumor suppressor gene p53의 발현}

대장암 세포주에서 capsaicin에 의한 전사조절인자인 p53 유전자의 발현을 확인하고, 또한 p53 유전자의 조절 하에 있는 전사조절 대상을 확인하는 것은 p53의 세포사멸과 capsaicin 에 의한 항암 기전을 이해하는데 매우 중요할 것으로 생각된 다. Capsaicin에 의한 p53의 발현 증가를 확인하기 위하여 대 장암 세포주 HCT116에 capsaicin을 농도별 $(0,25,50,100 \mu \mathrm{M})$ 


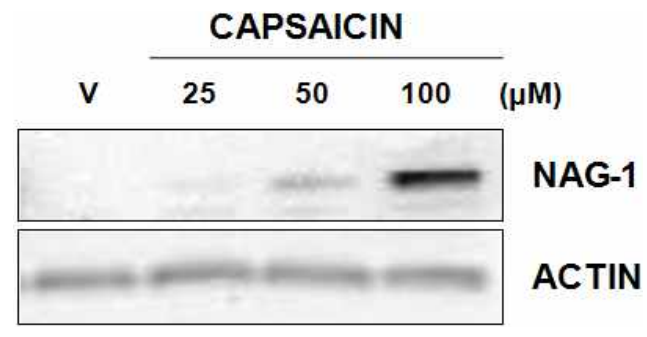

Fig. 3. NAG-1 protein expression by capsaicin. HCT116 cells were treated with different concentrations $(0,25,50,100$ $\mu \mathrm{M})$ of capsaicin for $24 \mathrm{hr}$. Total proteins were prepared from treated cell and used for Western blot analysis. NAG-1 antibody was treated followed by Actin antibody.

(A)

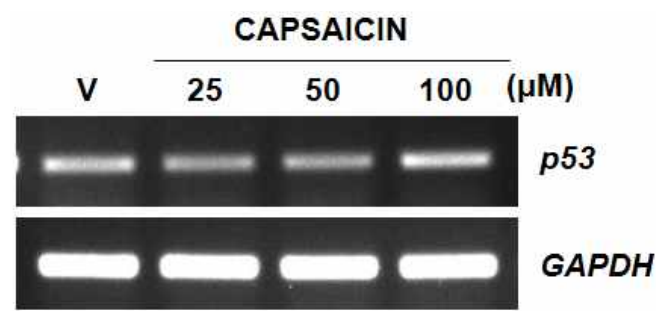

(B)

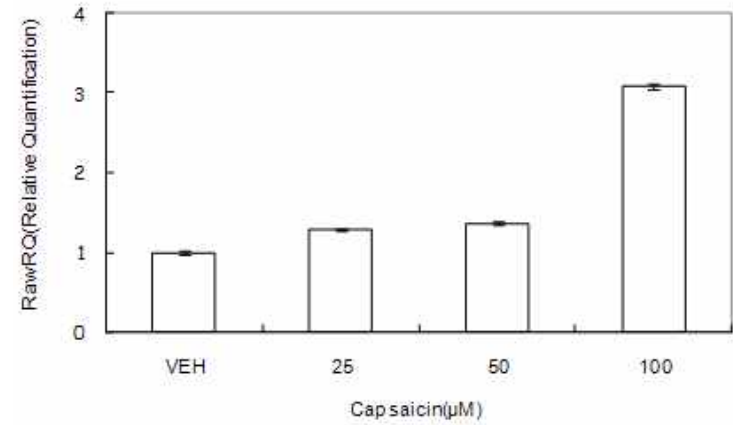

Fig. 4. p53 gene expression by capsaicin. HCT116 cells were treated with three different doses of capsaicin. (A) Total RNA was prepared from treated cells and used for RT-PCR with p 53 gene specific primers. (B) Total RNA was prepared from treated cells and used for real-time PCR with p53 gene-specific primers.

로 처리한 후, RT-PCR을 수행하였다. 그 결과 $25 \mu \mathrm{M}$ 와 50 $\mu \mathrm{M}$ capsaicin의 처리에 의해서는 p53 유전자의 발현이 보이지 않았고, $100 \mu \mathrm{M}$ capsaicin의 처리에 의해서만 p53 유전자가 발현됨을 확인할 수 있었다(Fig. 4A). 또한 capsaicin에 의한 $\mathrm{p} 53$ 의 발현 증가를 정량적으로 확인하기 위하여 real-time $\mathrm{PCR}$ 을 수행하였다. 그 결과 $25 \mu \mathrm{M}$ 와 $50 \mu \mathrm{M}$ capsaicin의 처리 에 의해서는 p53 유전자의 발현량이 대조군과 큰 차이를 보이 지 않은 반면, $100 \mu \mathrm{M}$ capsaicin을 처리하면 3.1배의 발현량을 보였다(Fig. 4B). 본 연구결과와 유사하게 최근 Mori 등은 전립 선암 세포주에서 capsaicin의 처리에 의해 세포사멸이 유도되 고, 더불어 p53, p21 등의 세포사멸 관련 유전자의 과대발현을 보고한 바 있다[21]. 또한, 이 결과는 cell viability assay에서
Table 2. Sequences of oligonucleotide primers used for RT-PCR and real-time PCR

\begin{tabular}{|c|c|c|}
\hline $\begin{array}{l}\text { Gene } \\
\text { name }\end{array}$ & $\begin{array}{l}\text { GenBank } \\
\text { Acc. No. }\end{array}$ & Sequence \\
\hline$N A G 1$ & NM_004864 & $\begin{array}{l}\text { F: 5'-CTCTCAGATGCTCCTGGTGT-3' } \\
\text { R: 5'-GAATATTCCCAGCTCTGGTT-3' }\end{array}$ \\
\hline DDIT3 & NM_004083 & $\begin{array}{l}\text { F: 5'-CATTGCCTTTCTCCTTCGGG-3' } \\
\text { R: 5'-TGCTGGTTCTGGCTCCTCCT-3' }\end{array}$ \\
\hline PCK2 & NM_004563 & $\begin{array}{l}\text { F: 5'-ACACGGTACAACTCCCGCCT-3' } \\
\text { R: 5'-ATACGCATGCTTGCCACCAC-3' }\end{array}$ \\
\hline$D 45 A$ & $\mathrm{NM}$ & $\begin{array}{l}\text { F: 5'-TGCGAGAACGACATCAACAT-3' } \\
\text { R: 5'-TCCCGGCAAAAACAAATAAG-3' }\end{array}$ \\
\hline$p 53$ & NM_000546 & $\begin{array}{l}\text { F: 5'-CTCACCATCATCACACTGGA-3' } \\
\text { R: } 5^{\prime} \text {-GAGAGGAGCTGGTGTTGTTG-3' }\end{array}$ \\
\hline$G A P D H$ & NM_002046 & $\begin{array}{l}\text { F: 5'-CTGACCTGCCGTCTAGAAAA-3' } \\
\text { R: 5'-GAGCTTGACAAAGTGGTCGT-3' }\end{array}$ \\
\hline
\end{tabular}

세포사멸이 시작되는 시점이 $100 \mu \mathrm{M}$ 의 capsaicin을 처리할 때인 점을 생각해 보면, capsaicin에 의한 세포사멸은 p53 유전 자의 발현과 밀접한 관계가 있음을 시사한다.

\section{유전자 발현의 암 억제유전자 p53 의존성 검증}

Capsaicin에 의한 p53 유전자의 발현 증가를 RT-PCR과 real-time PCR로 확인한 결과, $100 \mu \mathrm{M}$ capsaicin 처리에 의해서 만 p53 유전자가 발현됨을 확인할 수 있었다. 이 결과를 통해 capsaicin에 의한 세포사멸은 p53 유전자의 발현과 밀접한 관 련이 있는 것으로 생각된다. 따라서, capsaicin 처리에 의한 유전자의 발현이 p53 의존적인지 아닌지를 분석하는 것은 capsaicin의 항암 활성을 연구하는데 있어서 매우 중요하다고 생각된다. 본 연구에서는 Fig. 2에서 발현의 증가를 확인한 4 개 의 유전자를 대상으로, p53 유전자 null인 HCT116 세포주를

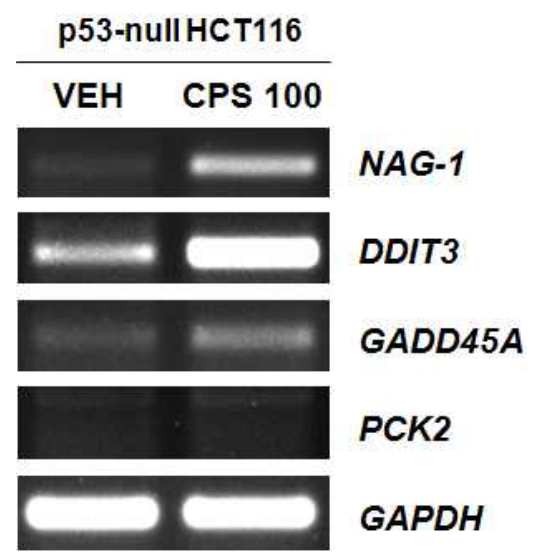

Fig. 5. Effect of $p 53$ on gene expression by capsaicin. p53-null HCT116 cells were treated with $100 \mu \mathrm{M}$ capsaicin for 24 $\mathrm{hr}$ and then RT-PCR was performed using gene-specific primers. 
이용하여 이들 유전자 발현의 p53 의존성 여부를 확인하였다. 그 결과 Fig. 5 에서 보는 바와 같이, NAG1, DDIT3, GADD45A 유전자는 p53 유전자의 존재와 관계없이 발현이 up-regulation 되는 것을 확인할 수 있었고, 이에 반해 $P C K 2$ 유전자의 발현은 p53이 존재해야만 up-regulation 된다는 것을 확인할 수 있었다. 그러나, 전사조절인자인 $\mathrm{p} 53$ 에 의해 $P C K 2$ 유전자 의 발현이 조절된다는 보고는 없어서, 이 두 유전자간의 조절 관계에 대해서는 좀 더 많은 연구가 진행되어야 할 것으로 생각된다. 결론적으로, 이러한 연구결과들은 capsaicin에 의한 항암 활성에 대한 분자생물학적 기전을 이해하는데 중요한 단서를 제공해 줄 것으로 기대된다.

\section{감사의 글}

본 연구는 2008학년도 안동대학교 학술연구조성비에 의해 연구되었으며, 이에 감사드립니다.

\section{References}

1. Baek, S. J., K. S. Kim, J. B. Nixon, L. C. Wilson, and T. E. Eling. 2001. Cyclooxygenase inhibitors regulate the expression of a TGF-beta superfamily member that has proapoptotic and antitumorigenic activities. Mol. Pharmacol. 59, 901-908

2. Baek, S. J., L. C. Wilson, and T. E. Eling. 2002. Resveratrol enhances the expression of non-steroidal anti-inflammatory drug-activated gene (NAG-1) by increasing the expression of p53. Carcinogenesis 23, 425-434.

3. Bates, S. and K. H. Vousden. 1996. p53 in signaling checkpoint arrest or apoptosis. Curr. Opin. Genet. Dev. 6, 12-18.

4. Biro, T., G. Acs, P. Acs, S. Modarres, and P. M. Blumberg. 1997. Recent advances in understanding of vanilloid receptors: a therapeutic target for treatment of pain and inflammation in skin. J. Investig. Dermatol. Symp. Proc. 2, 56-60.

5. Chou, C. C., Y. C. Wu, Y. F. Wang, M. J. Chou, S. J. Kuo, and D. R. Chen. 2009. Capsaicin-induced apoptosis in human breast cancer MCF-7 cells through caspase-independent pathway. Oncol. Rep. 21, 665-671.

6. Cordell, G. A. and O. E. Araujo. 1993. Capsaicin: identification, nomenclature, and pharmacotherapy. Ann. Pharmacother. 27, 330-336.

7. Ding, H., W. Duan, W. G. Zhu, R. Ju, K. Srinivasan, G. A. Otterson, and M. A. Villalona-Calero. 2003. p21 response to DNA damage induced by genistein and etoposide in human lung cancer cells. Biochem Biophys. Res. Commun. 305, 950-956.

8. el-Deiry, W. S., T. Tokino, V. E. Velculescu, D. B. Levy, R. Parsons, J. M. Trent, D. Lin, W. E. Mercer, K. W. Kinzler, and B. Vogelstein. 1993. WAF1, a potential mediator of p53 tumor suppression. Cell 75, 817-825.

9. Gupta, S., N. Ahmad, A. L. Nieminen, and H. Mukhtar. 2000. Growth inhibition, cell-cycle dysregulation, and in- duction of apoptosis by green tea constituent (-)-epigallocatechin-3-gallate in androgen-sensitive and androgeninsensitive human prostate carcinoma cells. Toxicol. Appl. Pharmacol. 164, 82-90.

10. Hail, N. Jr and R. Lotan. 2002. Examining the role of mitochondrial respiration in vanilloid-induced apoptosis. J. Natl. Cancer Inst. 94, 1281-1292.

11. Huang, C., W. Y. Ma, A. Goranson, and Z. Dong. 1999. Resveratrol suppresses cell transformation and induces apoptosis through a p53-dependent pathway. Carcinogenesis $20,237-242$.

12. Joo, J. J. 1999. Body-fat suppressive effects of capsaicin through $\beta$-adrenergic stimulation in rats fed a high-fat diet. The Korean Journal of Nutrition 32, 533-539.

13. Kim, C. S., W. H. Pack, J. Y. Park, J. H. Kang, M. O. Kim, T. Kawada, H. Yoo, I. S. Han, and R. Yu. 2004. Capsaicin, a spicy component of hot pepper, induces apoptosis by activation of the peroxisome proliferator-activated receptor gamma in HT-29 human colon cancer cells. J. Med Food7, 267-273.

14. Kim, J. S., S. J. Baek, T. Sali, and T. E. Eling. 2005. The conventional nonsteroidal anti-inflammatory drug sulindac sulfide arrests ovarian cancer cell growth via the expression of NAG-1/MIC-1/GDF-15. Mol. Cancer Ther. 4, 487-493.

15. Lee, J. S., J. S. Chang, J. Y. Lee, and J. A. Kim. 2004. Capsaicin-induced apoptosis and reduced released of reactive oxygen species in MBT-2 murine bladder tumor cells. Arch Pharm Res. 27, 1147-1153.

16. Lee, S. H., J. S. Kim, K. Yamaguchi, T. E. Eling, and S. J. Baek. 2005. Indole-3-carbinol and 3,3'-diindolylmethane induce expression of NAG-1 in a p53-independent manner. Biochem Biophys. Res. Commun. 328, 63-69.

17. Lee, Y. S., Y. S. Kang, J. S. Lee, S. Nicolova, and J. A. Kim. 2004. Involvement of NADPH oxidase-mediated generation of reactive oxygen species in the apoptotic cell death by capsaicin in HepG2 human hepatoma cells. Free Radic. Res. 38, 405-412.

18. Levine, A. J. p53, the cellular gatekeeper for growth and division. 1997. Cell 88, 323-331.

19. Livak, K. J. and T. D. Schmittgen. 2001. Analysis of relative gene expression data using real-time quantitative PCR and the 2(-Delta Delta C(T)) Method. Methods 25, 402-408.

20. Malagarie-Cazenave, S, N. Olea-Herrero, D. Vara, and I. Díaz-Laviada. 2009. Capsaicin, a component of red peppers, induces expression of androgen receptor via PI3K and MAPK pathways in prostate LNCaP cells. FEBS Lett. 583, 141-147.

21. Mori, A., S. Lehmann, J. O'Kelly, T. Kumagai, J. C. Desmond, M. Pervan, W. H. McBride, M. Kizaki, and H. P. Koeffler. 2006. Capsaicin, a component of red peppers, inhibits the growth of androgen-independent, p53 mutant prostate cancer cells. Cancer Res. 66, 3222-3229.

22. Sánchez, A. M., J. Martínez-Botas, S. Malagarie-Cazenave, N. Olea, D. Vara, M. A. Lasunción, and I. Díaz-Laviada. 2008. Induction of the endoplasmic reticulum stress protein GADD153/CHOP by capsaicin in prostate PC-3 cells: a mi- 
croarray study. Biochem Biophys. Res. Commun. 372, 785-791.

23. Surh, Y. J., K. S. Chun, H. H. Cha, S. S. Han, Y. S. Keom, K. K. Park, and S. S. Lee. 2001. Molecular mechanisms underlying chemopreventive activities of anti-inflammatory phytochemicals: down-regulation of COX-2 and iNOS through suppression of NF-kappa B activation. Mutat. Res. 480, 243-268.

24. Surh, Y. J. and L. R. Ferguson. 2003. Dietary and medicinal antimutagens and anticarciongens: molecular mechanism and chemopreventive potential-highlights of a symposium. Mutat. Res. 523-524, 1-8.

25. Surh, Y. J. 2003. Cancer chemoprevention with dietary phytochemicals. Nature Reviews Cancer 3, 768-780.

26. Szallasi, A. and P. M. Blumberg. 1999. Vanilloid (Capsaicin) receptors and mechanisms. Pharmacol. Rev. 51, 159-212.

27. Thomas, K. C., A. S. Sabnis, M. E. Johansen, D. L. Lanza,
P. J. Moos, G. S. Yost, and C. A. Reilly. 2007. Transient receptor potential vanilloid 1 agonists cause endoplasmic reticulum stress and cell death in human lung cells. $J$. Pharmacol. Exp. Ther. 321, 830-838.

28. Vogelstein, B. and K. W. Kinzler. 1992. p53 function and dysfunction. Cell 70, 523-526.

29. Watabe, M., K. Hishicawa, A. Takyanaqi, N. Shimizu, and T. Nakaki. 2004. Caffeic acid phenethyl ester induces apoptosis by inhibition of NF-kappaB and activation of Fas in human breast cancer MCF-7 cell. J. Biol. Chem 279, 6017-6026.

30. Wilson, L. C., S. J. Baek, A. Call, and T. E. Eling. Nonsteroidal anti-inflammatory drug-activated gene (NAG-1) is induced by genistein through the expression of p53 in colorectal cancer cells. Int. J. Cancer 105, 747-753.

\section{초록 : 인간 대장암 세포주에서 capsaicin 처리에 의한 차별적인 유전자 발현의 p53 의존성 분석}

김효은 · 장민정 · 임승현 · 김효림 · 김순영 · 이건주 · 김종식*

(안동대학교 자연과학대학 생명과학과)

본 연구에서는 대장암 세포주 모델에서 파이토케미칼 capsaicin에 의한 항 생장 활성과 유전체 수준에서의 유전 자 발현 변화를 연구하였다. 그 결과, 처리한 capsaicin 농도 의존적으로 세포 생존율이 감소함을 확인하였고, capsaicin은 다양한 유전자의 발현 변화를 유도하였다. DNA microarray 실험결과 $100 \mu \mathrm{M}$ capsaicin의 처리에 의해 2 배 이상 증가되는 유전자 103 개가 확인된 반면, 2 배 이상 발현이 감소되는 유전자 153 개가 확인되었다. 발현이 증가되는 유전자 중 4개(NAG-1, DDIT3, GADD45A 그리고 PCK2를 선택하여 RT-PCR을 수행한 결과, DNA micorarray 실험과 일치함을 확인하였다. 또한 $100 \mu \mathrm{M}$ capsaicin의 처리에 의해 암 억제유전자인 p53의 발현이 증가 됨을 RT-PCR과 real-time PCR 방법으로 확인하였다. 게다가, NAG-1, DDIT3 그리고 GADD45A 유전자는 p53의 존재에 관계없이 발현이 증가되는 반면, $P C K 2$ 유전자는 반드시 $\mathrm{p} 53$ 에 의해 발현이 유도됨을 확인할 수 있었다. 이러한 연구는 대장암 세포주에서 capsaicin에 의한 항암 기전을 이해하는데 도움을 줄 것으로 기대된다. 